\title{
Clinical and Radiological Findings in Children with Cerebral Sinovenous Thrombosis
}

\section{Serebral Sinovenöz Trombozlu Çocuklarda Klinik ve Radyolojik Bulgular}

\author{
Hulya MARAS GENC ${ }^{1}$, Sevinc KALIN² , Buşra KUTLUBAY ${ }^{1}$, Hatice Gulhan SOZEN"1, \\ Funda TEKKESSIN ${ }^{3}$, Fikret ASARCIKLI ${ }^{3}$, Burcu KARAKAYALI ${ }^{4}$, Betul SOZERI ${ }^{5}$
}

${ }^{1}$ University of Health Sciences, Ümraniye Training and Research Hospital, Department of Pediatrics, Section of Pediatric Neurology, İstanbul, Turkey

2University of Health Sciences, Ümraniye Training and Research Hospital, Department of Radiology, Section of Pediatric Radiology, İstanbul, Turkey

${ }^{3}$ University of Health Sciences, Ümraniye Training and Research Hospital, Department of Pediatrics, Section of Pediatric HematologyOncology, İstanbul, Turkey

${ }^{4}$ University of Health Sciences, Ümraniye Training and Research Hospital, Department of Pediatrics, İstanbul, Turkey

${ }^{5}$ University of Health Sciences, Ümraniye Training and Research Hospital, Department of Pediatrics, Division of Pediatric Rheumatology, İstanbul, Turkey

\section{ABSTRACT}

Objective: Cerebral sinovenous thrombosis (CSVT) is increasingly recognized in children with advanced use of neuroimaging techniques. In this study, we aimed to present clinical and radiologic features of CSVT in children.

Material and Methods: Children aged 1 month to 18 years old diagnosed with CSVT were retrospectively analyzed. Demographic and clinical data of patients including age at diagnosis, sex, presenting symptoms and signs, risk factors for thrombosis, treatment and prognosis were collected.

Results: Twelve children were included in the study, 8 of them were male. Headache $(n=7)$, seizures $(n=5)$ and visual impairment $(n=4)$ were the most common presenting symptoms. The superficial venous system was involved in all patients, in five patients deep venous system was also involved. Parenchymal involvement was present in three patients. Two children had isolated cortical vein thrombosis. All patients had underlying risk factors. Five children had recent infections, six children were diagnosed with Behçet's disease, three with mastoiditis. High lipoprotein (a) level was found

(1)

MARAS GENC H

KALIN S

KUTLUBAY B

SOZEN HG

TEKKESIN F

ASARCIKU

ASARCIKLIF

SOZERI B
0000-0001-8869-0277 :0000-0001-9417-2847 0000-0002-6216-1438 0000-0002-3613-0814 $0000-0002-0487-5643$

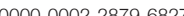
(0000-0002-2879-6827 0000-0003-0358-6409
Conflict of Interest / Cıkar Catıșması: On behalf of all authors, the corresponding author states that there is no conflict of interest.

Ethics Committee Approval / Etik Kurul Onayı: University of Health Sciences Ümraniye Training and Research Hospital Clinical Researches Ethical Board approved the study (17/04/2019-8336).

Contribution of the Authors / Yazarların katkısı: MARAS GENC H: Constructing the hypothesis or idea of research and/or article, Planning methodology to reach the Conclusions, Organizing, supervising the course of progress and taking the responsibility of the research/study, Taking responsibility in patient follow-up, collection of relevant biological materials, data management and reporting, execution of the experiments, Taking responsibility in necessary literature review for the study, Taking responsibility in the writing of the whole or important parts of the study, Reviewing the article before submission scientifically besides spelling and grammar. KALIN S: Planning methodology to reach the Conclusions, Organizing, supervising the course of progress and taking the responsibility of the research/study, Taking responsibility in patient follow-up, collection of relevant biological materials, data management and reporting, execution of the experiments, Taking responsibility in logical interpretation and conclusion of the results, Taking responsibility in necessary literature review for the study, Taking responsibility in the writing of the whole or important parts of the study, results, Taking responsibility in necessary literature review for the study, Taking responsibility in the writing of the whole or important parts of the study,
Reviewing the article before submission scientifically besides spelling and grammar. KUTLUBAY B: Constructing the hypothesis or idea of research and/or article, Organizing, supervising the course of progress and taking the responsibility of the research/study, Taking responsibility in patient follow-up, collection of relevant biological materials, data management and reporting, execution of the experiments, Taking responsibility in logica interpretation and conclusion of the results, Taking responsibility in necessary literature review for the study, Taking responsibility in the writing of the whole or important parts of the study, Reviewing the article before submission scientifically besides spelling and grammar. SOZEN HG: Constructing the hypothesis or idea of research and/or article, Organizing, supervising the course of progress and taking the responsibility of the research/study, responsibility in the writing of the whole or important parts of the study, Reviewing the article before submission scientifically besides spelling and grammar. TEKKESIN F: Taking responsibility in patient follow-up, collection of relevant biological materials, data management and reporting, execution of the experiments, Taking responsibility in logical interpretation and conclusion of the results, Taking responsibility in necessary literature review fo the study, Taking responsibility in the writing of the whole or important parts of the study, Reviewing the article before submission scientifically besides spelling and grammar. ASARCIKLI F: Taking responsibility in patient follow-up, collection of relevant biological materials, data management and reporting, execution of the experiments, Taking responsibility in logical interpretation and conclusion of the results, Taking responsibility in necessan literature review for the study, Taking responsibility in the writing of the whole or important parts of the study, Reviewing the article before submission scienticaly besides spelling and grammar. KARAKAYALI T data management and reporting, execution of the experiments, Taking responsibility in logical interpretation and conclusion of the results, Taking responsibility in necessary literature review for the study, Taking responsibility in the writing of the whole or important parts of the study, Reviewing the article before submission scientifically besides spelling and grammar. SOZERI B: Taking responsibility in patient follow-up, collection of relevan biological materials, data management and reporting, execution of the experiments, Taking responsibility in logical interpretation and conclusion of the results, Taking responsibility in necessary literature review for the study, Taking responsibility in the writing of the whole or important parts of the study, Reviewing the article before submission scientifically besides spelling and grammar.

How to cite / Atıf yazım şekli : Maras Genc H, Kalın S, Kutlubay B, Sozen HG, Tekkesin F, Asarcıklı F et al. Clinical and Radiological Findings in Children with Cerebral Sinovenous Thrombosis. Turkish J Pediatr Dis 2022;16:179-185.
Correspondence Address / Yazıșma Adresi:

\section{Hulya MARAS GENC}

University of Health Sciences,

Ümraniye Training and Research Hospital, Department of Pediatrics,

Section of Pediatric Neurology, Istanbul, Turkey

E-posta: hulyamaras@gmail.com
Received / Geliş tarihi : :06.01.2021 Accepted / Kabul tarihi : 28.05.2021 Online published Elektronik yayın tarihi

DOI: 10.12956/tchd.852458 
in two patients. One patient had a diagnosis of acute lymphoblastic leukemia and received I-asparaginase treatment. All patients were treated with anticoagulants. One patient received tissue plasminogen activator, complicated with intracranial bleeding. Three patients with parenchymal involvement had moderate to severe motor impairment. All patients presenting with seizure had parenchymal involvement and followed up with epilepsy.

Conclusion: CSVT causes significant morbidity. Especially in older children presenting with CSVT, symptoms and signs of Behçet's disease should be questioned. Mastoiditis is still an important reason for CSVT in children.

Key Words: Intracranial, Magnetic resonance imaging, Sinus thrombosis, Risk factors, Treatment, Prognosis

\section{ÖZ}

Amaç: Serebral sinovenöz tromboz (CSVT), ileri nörogörüntüleme yöntemlerinin yaygın olarak kullanılması ile, çocuklarda giderek daha fazla tanınmaktadır. Bu çalışmada CSVT tanısı alan çocukların klinik ve radyolojik bulgularını sunmayı amaçladık.

Gereç ve Yöntemler: Bir ay - 18 yaş arasında CSVT tanısı alan çocuklar retrospektif olarak analiz edildi. Demografik özellikler ve tanı anındaki yaş, cinsiyet, başvuru semptom ve bulguları, tromboz risk faktörleri, tedavi ve prognoza dair klinik veriler değerlendirildi.

Bulgular: Çalışmaya 12 çocuk dahil edildi, 8'i erkekti. Baş ağrısı $(n=7)$, nöbet $(n=5)$ ve görme bozukluğu ( $n=4)$ en sık görülen başvuru semptomlarıydı. Tüm çocuklarda yüzeyel venöz sistem tutulmuştu, 5 hastada derin venoz sistem tutulumu vardı. Parenkimal tutulum 3 hastada izlendi. İki çocukta izole kortikal ven trombozu mevcuttu. Tüm çocuklarda altta yatan risk faktörleri vardı. Beș hastada yakın zamanda enfeksiyon öyküsü mevcuttu, 6 hastada Behçet hastalığı, 3 hastada mastoidit, 2 hastada lipoprotein (a) yüksekliği mevcuttu. Bir hastada akut lenfoblastik lenfoma tanısı vardı, I-asparajinaz ve steroid tedavileri alıyordu. Tüm hastalar antikoagulan tedavi aldı. Doku plazminojen aktivatörü verilen bir hastada intrakraniyal kanama geliști. Parenkimal tutulum olan 3 hastada orta-ileri motor bozukluk geliști. Nöbetle başvuran tüm hastalarda parenkimal tutulum vardı ve hepsi epilepsi tanısı ile izleme alındı.

Sonuç: CSVT önemli bir morbidite nedenidir. Özellikle CSVT tanıSı alan büyük çocuklarda Behçet hastalığı semptom ve bulguları sorgulanmalıdır. Mastoidit çocuklarda CSVT'nin halen önemli nedenlerinden biridir.

Anahtar Sözcükler: İntrakraniyal, Manyetik rezonans görüntüleme, Sinovenöz tromboz, Risk faktörü, Tedavi, Prognoz

\section{INTRODUCTION}

Cerebral sinovenous thrombosis (CSVT) is rare relative to arterial stroke in children, but with the widespread use of radiologic facilities, it is increasingly recognized. The incidence of pediatric CSVT is reported as 0.67 per 100.000 children per year, with a higher incidence in neonates in Canada (1). In a German cohort, the incidence of CSVT is reported as 2.6 per 100.000 in neonates compared with 0.35 per 100.000 in older children (2). Symptoms and signs are diverse and non-specific; late diagnosis may be associated with significant morbidity and mortality (3). Neurologic presentations may be different according to age, location and extent of thrombosis, and accompanying parenchymal involvement (4). Local or systemic infections, dehydration, malignancy, nephrotic syndrome, drug toxicity, prothrombotic disorders, inflammatory diseases, metabolic disorders have been described as risk factors for CSVT $(1,2,4,5)$. In this study, we aimed to analyze children diagnosed with CSVT in our clinic, and emphasize different clinical and radiologic presentations and risk factors of CSVT.

\section{MATERIALS and METHODS}

Twelve children aged 1 month to 18 years old diagnosed with CSVT hospitalized in Umraniye Training and Research Hospital during January 2017- December 2020 were retrospectively analyzed. Neonates were not included. Diagnosis of CSVT was confirmed by magnetic resonance imaging (MRI), and magnetic resonance venography (MRV). Demographic and clinical data of patients including age at diagnosis, sex, presenting symptoms and signs, risk factors for thrombosis, treatment and prognosis were collected. The radiologic evaluation included thrombosis site, parenchymal involvement. The location of thrombosis was classified as superficial (including sagittal, transverse, sigmoid, confluence sinuses and cortical veins) and deep (straight sinus, internal cerebral vein, jugular vein, medullary veins). All MRI studies were obtained with a 1.5 Tesla MRI (Siemens Magnetom Aera Healthcare); and included T1 and T2-weighted, fluid-attenuated inversion recovery, T2 gradient echo imaging, diffusion-weighted imaging, apparent diffusion coefficient maps, T2-hemogradient and 2D time-of-flight MR venography. We added contrast-enhanced T1-weighted imaging, contrast-enhanced MR venography and susceptibilityweighted images when necessary. All patients underwent the following investigations: Complete blood count, C-reactive protein, sedimentation, protein $\mathrm{C}$, protein $\mathrm{S}$, fibrinogen level, anti-thrombin III level, factor VIII, factor IX, activated protein C resistance, prothrombin time, activated thromboplastin time, anti-cardiolipin factors, homocysteine levels; and for genetic investigations, factor V Leiden, factor II G20210A, and methyltetrahydrofolate reductase (MTHFR) were studied. Additional rheumatologic tests including antinuclear antibody, extractable nuclear antigen panel, and pathergy tests were performed when necessary. Cerebrospinal fluid pressure (CSF) was measured in patients with clinical findings of increased intracranial pressure if there are no contraindications for lumbar puncture. University of Health Sciences Umraniye Training and 
Research Hospital Clinical Researches Ethical Board approved the study (17/04/2019-8336).

\section{RESULTS}

Twelve children [4 girls (33\%), 8 boys (67\%], median age 10 years, age range 2 months to 17 years) with CSVT were included in the study. The clinical and radiologic findings of patients are summarized in table I.

Three patients (25\%) had hyper-acute onset presenting in hours, six patients (50\%) had acute onset, presenting in days. Two patients (17\%) had subacute onset presenting in 1-2 months. One of them (patient-5) had paroxysmal dysesthesia and dysphasia; which were evaluated as focal non-motor seizures with sensorial and cognitive elements. The seizure semiology was compatible with the cortical lesion secondary to cortical vein thrombosis. Another patient (patient-7) had a history of headache for two months, diplopia for two days. After diplopia, he was evaluated by an ophthalmologist and papilledema was detected. One patient (patient-8) was asymptomatic for CSVT, her cranial MRI was performed after a prolonged seizure and sigmoid vein thrombosis was found incidentally. She had mild cognitive impairment and copy number variation. Three patients with hyper-acute onset (patient-1, patient-4, and patient-11) had brain edema, parenchymal hemorrhage with mass effect and midline shift, and presented with a decreased level of consciousness. Eight patients (67\%) presented with increased intracranial pressure symptoms; headache and papilledema were present in six, abducens palsy was present in two of them. The headache pattern was progressive in all patients. CSF opening pressure was measured in four patients with increased intracranial pressure symptoms and/or signs and was found to be $22-68 \mathrm{~cm}-\mathrm{H}_{2} \mathrm{O}$ (Table I). In three patients, lumbar puncture was not performed because of the mass effect due to intracranial hemorrhage. One patient (patient-10) was receiving antibiotics for mastoiditis and $\mathrm{LMWH}$. When he presented to our clinic, there was no papilledema and visual field testing was normal; for this reason, lumbar puncture was not performed. Seizures were present in five patients (42\%), two of them with cortical vein thrombosis presented with focal aware seizures, all had parenchymal involvement. Two patients $(17 \%)$ were febrile at presentation.

Both superficial and deep venous system were involved in 5 patients (42\%); only superficial venous system was involved in 7 (58\%) patients. Sinuses involved were transverse sinus $(n=7$, $58 \%)$ sigmoid sinus $(n=7,58 \%)$, superior sagittal sinus $(n=6$, $50 \%)$. Isolated cortical vein thrombosis (ICVT) was present in two patients (17\%) (Figure 1). Parenchymal involvement and accompanying hemorrhagic lesions were present in five (42\%) patients (figure 2 and 3). Figure 4 shows patient 7 and patient
12 with BD and diffuse CSVT. Extracranial venous thrombosis was present in one patient (patient-4): thrombosis was present in the right brachial, right subclavian and left femoral veins.

Risk factors for CSVT were dehydration and diarrhea in one patient (patient 1, 54-day-old infant); mastoiditis in three patients, Behçet's disease (BD) in six patients (three of them diagnosed with BD after diagnosis of CSVT), elevated 'lipoprotein a' in two patients, head\&neck surgery (adenotonsillectomy) history in one patient, acute lymphoblastic leukemia and l-asparaginase treatment in one patient. MTHFR A1298C, MTHFR C677T heterozygous mutations were found in patient 1, 4 and 6; F V Leiden G1691 heterozygous mutation was also found in patient 1 and 6.

Patient-1 and patient-11, received intravenous unfractionated heparin infusion, because of the existing hemorrhagic lesion and for close monitoring of anticoagulation in case for quick reversal. Patient- 4 received tissue plasminogen activator (tPA) in another hospital pediatric intensive care unit, because of rapid clinical deterioration, but after intracranial hemorrhage developed, tPA was stopped. Transition to LMWH occurred after the acute stage in patient 1, 4 and 11. Patient 1 and patient 4 needed surgical intervention for increased intracranial pressure. A ventriculo-peritoneal shunt was inserted in patient-1, and decompressive craniectomy was performed in patient-4. All other patients used LMWH at diagnosis. All patients received a treatment dose of LMWH till recanalization, and then a prophylactic dose for 6 months. Three patients with CSVT secondary to mastoiditis had increased CSF pressure, and received antibiotics and acetazolamide and/or topiramate. Five patients (42\%) presenting with seizures received antiepileptic treatment. They all had parenchymal involvement, and continued antiepileptic treatment with a diagnosis of epilepsy. Patient 7, 9, 10, 12 with a diagnosis of BS before CSVT diagnosis, received pulse steroids and cyclophosphamide for acute exacerbation of the disease. Patient 4 and 5 were diagnosed as BD after CSVT, and colchicine therapy was started.

Follow-up ranged from 12 months to 24 months (median 18.5 months). Two patients (patient 1 and 4) with acute presentation had a severe motor and cognitive impairment. Patient- 1 was two-years-old at the last follow-up. He had left hemiplegia, was unable to stand without support, he had no meaningful word. He was on phenobarbital and levetiracetam therapy. Patient- 4 was 12 years old at the last-follow-up, she was hemiplegic and non-ambulatory. Two patients with ICVT who presented with recurrent seizures are followed with symptomatic epilepsy, but seizures were controlled within one to three weeks. In three patients presenting with headache, diplopia, papilledema; symptoms and signs resolved after medical treatment. There was no relapse in CSVT during the follow-up. 


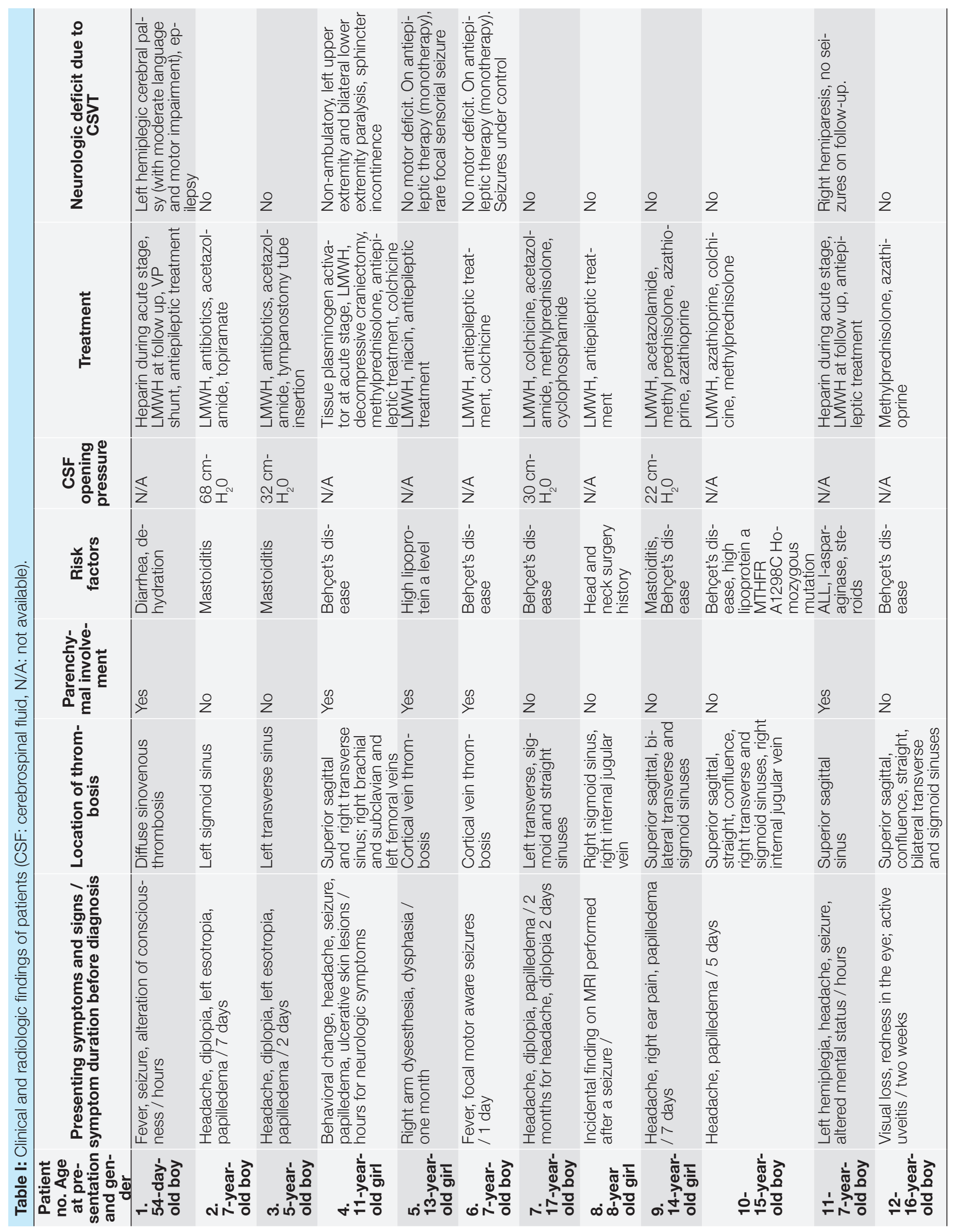




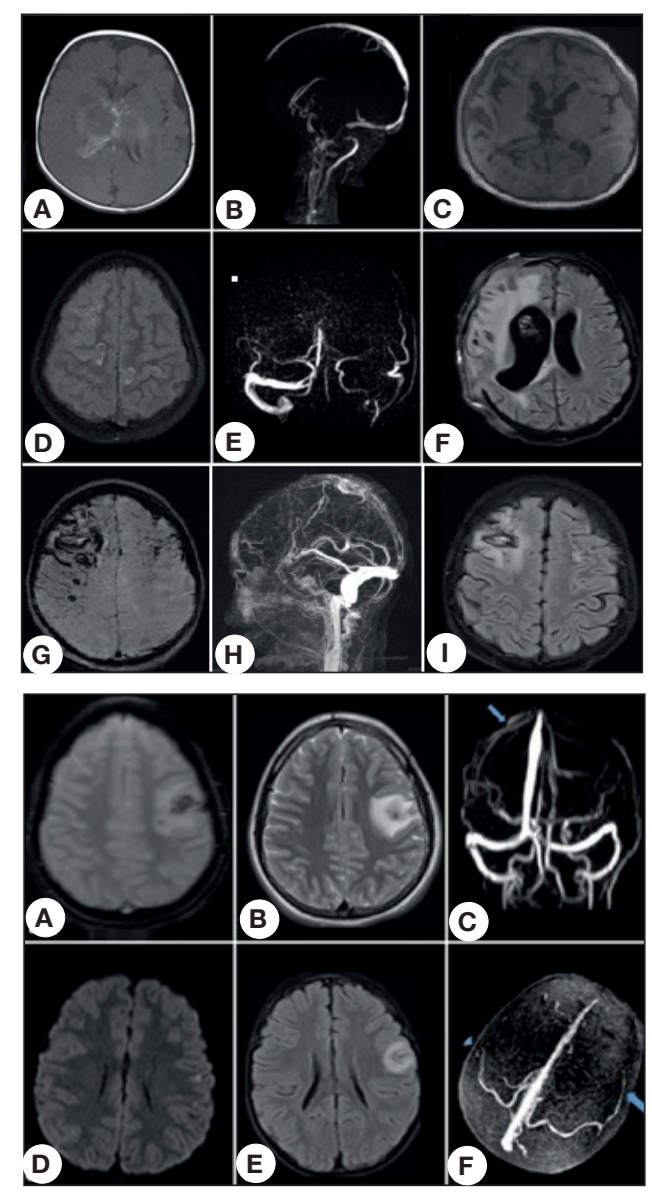

Figure 2: Patient 5 (A-C) and 6 (D-F) with cortical vein thrombosis. Axial hemogradient (A) and T2-weightes sequences show hemorrhagic focus in the centre of the lesion at the left parietal cortical and subcortical area. MR venography (C) shows trolard vein thrombosis; blue arrow indicates normal trolard vein in the right hemisphere, in the left side trolard vein is not seen due to thrombosis. Patient 6 , diffusion weighted sequence (D) shows diffusion restriction in the subcortical area of left parietal lobe, 3 days after presentation T2 weighted axial sequence (E) shows edema and cortical-subcotical blurring at the same location. MR venography (F) 3-D image shows filling defect on the distal part of the left trolard vein due to thrombosis (arrowhead), normal vascular filling of trolard vein is seen on the right side (arrow).

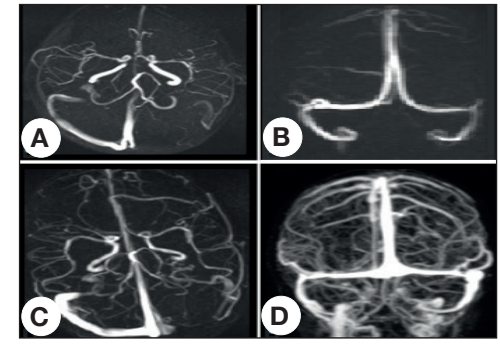

Figure 3: MR venography of patient 2 and 3 with sinus vein thrombosis secondary to mastoiditis. Patient 2, left sigmoid sinus thrombosis at initial presentation (A), and recanalisation after 5 months (B). Patient 3, left transverse sinus thrombosis at initial presentation (C), and recanalisation after 4 months (D).

\section{DISCUSSION}

In this study, we analyzed clinical and radiologic findings of children with a diagnosis of CSVT in a single center. Male predominance was seen in our study, similar to previous studies $(1,5,6)$. The clinical manifestations of CSVT are non-specific, it may be underdiagnosed, or diagnosis may be delayed especially in patients with chronic symptoms. In our cohort; headache, seizures and visual impairment were the most common findings. One patient with mild cognitive impairment was asymptomatic. She had a history of adenotonsillectomy
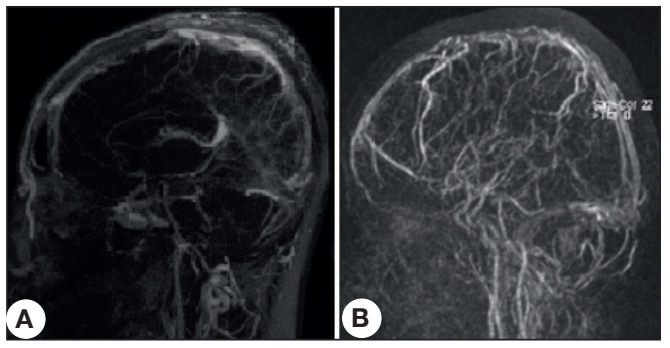

Figure 4: MR venography of patient 7 (A) and 12 (B) with Behçet's disease. Absence of flow due to diffuse cerebral sinovenous thrombosis, and compensatory increase in number and calibration of superficial cortical veins are seen in this figure.

procedure, which may be the reason for CSVT. Her symptoms may overlap with postoperative symptoms, or she may not be expressing her symptoms well. Two patients with ICVT had focal seizures related to parenchymal involvement; one of them with a focal non-motor seizure had a late diagnosis since paroxysmal sensorial and cognitive symptoms were not perceived as an urgent neurologic complaint by the parents. Most patients had symptoms and signs of increased intracranial pressure; headache was present in more then half of patients. In three large pediatric series, headache was present in 32.6$68 \%$, seizures were present in $37.9-48 \%$, cranial nerve palsies 9.5-33\% of children with CSVT $(1,2,5)$. 
$\mathrm{MRI}$ and contrast-enhanced MR venography are choices of imaging for diagnosis and follow-up of CSVT patients (7). Computerized tomography (CT) can be used in acute care management, though it has a lower sensitivity for CSVT (1). Findings in CSVT include; lack of blood flow in cerebral veins with or without parenchymal infarcts, thrombosis can be seen in on MRI in the subacute phase. T2-weighted gradient-echo sequences are very sensitive to paramagnetic products of hemoglobin. Diffusion-weighted imaging, apparent diffusion coefficient maps and,T2-weighted gradient-echo sequences are useful for thrombus imaging $(1,5,8)$.

In our study, multiple sinus involvement was present in most of the children, and $41.7 \%$ had associated parenchymal infarct. Our findings were similar to previous studies; around half of infants and children had multiple sinuses and/or veins involved and $38.5-41 \%$ had associated parenchymal infarcts $(1,7)$.

ICVT is rare and usually reported as case reports or small series. Diagnosis may be even difficult with neuroimaging, due to variation in cortical veins, and difficulty to identify occluded small cortical veins (8). T2-weighted gradient-echo sequence, magnetic susceptibility effect of hemoglobin products within the thrombus is an important diagnostic marker (8). In a pediatric study, by Ritchey et al. (9), seizures, altered mental status, parenchymal hemorrhage and restricted diffusion were more commonly seen then in CSVT other than cortical vein thrombosis. Similarly, in our study, two patients with ICVT presented with seizures; they had a parenchymal hemorrhage, and diffusion restriction and magnetic susceptibility effect was detected on T2-weighted gradient-echo images.

In our cohort, risk factors were present in all children. Mastoiditis is a rare complication of otitis media in children with declining incidence due to widespread use of antibiotic drugs. However, it still an important cause of CSVT in children $(1,10)$. In a study of 42 children with CSVT by Sebire et al. (5), $47 \%$ had mastoiditis. Two of three of our patients with mastoiditis presented with increased intracranial hypertension findings; abducens palsy and grade 4 papilledema were present in both of them. Although papilledema resolved in months; no neurologic or visual sequels occurred.

$\mathrm{BD}$ is a chronic inflammatory disease that can affect any type and size of the vessel, particularly the veins, and manifests with recurrent oral and/or genital ulcers, accompanied by the involvement of skin, eyes, and joints, as well as the gastrointestinal and central nervous systems. It has a higher prevalence along the Silk Route (highest in Turkey, then Iran, Japan and Korea). Neurological involvement is seen in 3.6\%$36 \%$ of pediatric patients $(11-13)$

Parenchymal lesions are distributed in the brain stem, spinal cord, basal ganglia, and cerebral white matter, and they lead to the clinical picture of the Neuro-BD (14). CSVT and pseudotumor cerebri are related to the non-parenchymal vascular form. Parenchymal lesions are more common in adults, whereas nonparenchymal lesions are more common in children and have a better prognosis (11).

In a retrospective study by Ünver et al. (15); 3 out of 11 CSVT patients were diagnosed with BD. Demir et al. (16), evaluated 12 children with CSVT and BD; half of them presented with CSVT and diagnosed with BD after neurologic involvement. Subacute presentation is common in $\mathrm{BD}$, with severe headache progressing in weeks (11). Treatment of CSVT in BD consists of high dose steroids since the pathogenesis is thought to be due to endothelial inflammation (17). The use of anti-coagulant agents is controversial, because patients with BD may also have pulmonary or other aneurysms, associated with an increased risk of bleeding (18). However, in recent studies, no increased risk of bleeding was reported in patients who received anticoagulation $(16,19)$. Although our study presents a small series, six patients were diagnosed with BD; three of them had diagnosis after presentation with CSVT. Four of them were referred to our hospital for rheumatologic evaluation. All received immunosuppressive treatment and anticoagulation. One patient received t-PA, in another center, for the mass effect of CSVT and parenchymal edema, and it was stopped after intracranial hemorrhage. There were no complications in the other five patients. BD symptoms and signs should be evaluated in adolescents presenting with CSVT.

All patients were screened for prothrombotic disorders. Two of them had increased lipoprotein a level, and one received prothrombotic agent; I-asparaginase. In a large cohort with a control group by Heller et al. (2), increased lipoprotein (a) was found to be the most important independent prothrombotic risk factor in pediatric patients with CSVT, followed by protein C deficiency.

In our cohort, mortality was not observed, but moderate to severe neurologic impairment was seen in three patients. None of the patients without parenchymal involvement had neurologic deficit secondary to CSVT. Instead of location or number of sinuses involved; parenchymal involvement was more related neurologic outcome; including epilepsy and motor impairment in our cohort. In the study by deVeber et al. (1), the adverse neurologic outcome was related with seizures at presentation and the presence of hemorrhagic or non-hemorrhagic infarcts. Sebire et al. (5), reported that good cognitive outcome was related with older age, lack of parenchymal abnormality and anticoagulation.

\section{CONCLUSION}

CSVT is a rare disorder, diagnosis may be missed or delayed due to non-specific presentation. In this small cohort we presented children with different clinic and radiologic features. Mastoiditis and BD are important causes of CSVT in children. $\mathrm{BD}$ symptoms and signs should be questioned in children with CSVT and CSVT should be suspected in children with 
headache and a diagnosis of BD. Motor deficits and epilepsy were more common in patients with parenchymal involvement.

\section{REFERENCES}

1. deVeber G, Andrew M, Adams C, Bjornson B, Booth F, Buckley DJ, et al. Cerebral sinovenous thrombosis in children. N Engl J Med 2001; 345: 417-23.

2. Heller C, Heinecke A, Junker R, Knöfler R, Kosch A, Kurnik K, et al. Cerebral venous thrombosis in children: a multifactorial origin. Circulation 2003;108:1362-67.

3. Carvalho KS, Bodensteiner JB, Connolly PJ, Garg BP. Cerebral venous thrombosis in children. J Child Neurol. 2001;16: 574-80.

4. Hedlund GL. Cerebral sinovenous thrombosis in pediatric practice. Pediatr Radiol 2013; 43:173-88.

5. Sébire G, Tabarki B, Saunders DE, Leroy I, Liesner R, Saint-Martin $\mathrm{C}$, et al. Cerebral venous sinus thrombosis in children: risk factors, presentation, diagnosis and outcome. Brain 2005; 128:477-89.

6. Golomb MR, Fullerton HJ, Nowak-Gottl U, Deveber G; International Pediatric Stroke Study Group. Male predominance in childhood ischemic stroke: findings from the international pediatric stroke study. Stroke 2009;40: 52-7.

7. Lolli V, Molinari F, Pruvo JP, Soto Ares G. Radiological and clinical features of cerebral sinovenous thrombosis in newborns and older children. J Neuroradiol 2016; 43:280-9.

8. Boukobza M, Crassard I, Bousser MG, Chabriat H. MR Imaging Features of Isolated Cortical Vein Thrombosis: Diagnosis and Follow-Up. AJNR Am J Neuroradiol 2009; 30: 344-48.

9. Ritchey Z, Hollatz AL, Weitzenkamp D, Fenton LZ, Maxwell EC, Bernard TJ, et al. Pediatric Cortical Vein Thrombosis: Frequency and Association With Venous Infarction. Stroke 2016; 47: 866-8
10. Zanoletti E, Cazzador D, Faccioli C, Sari M, Bovo R, Martini A. Intracranial venous sinus thrombosis as a complication of otitis media in children: Critical review of diagnosis and management. Int J Pediatr Otorhinolaryngol 2015; 79: 2398-403.

11. Uygunoğlu U, Siva Aksel. Behçet's Syndrome and Nervous System Involvement. Curr Neurol Neurosci Rep 2018;18:35.

12. Karincaoglu Y, Borlu M, Toker SC, Akman A, Onder M, Gunasti $S$, et al. Demographic and clinical properties of juvenile-onset Behcet's disease: A controlled multicenter study. J Am Acad Dermatol. 2008;58:579-84.

13. Gallizzi R, Pidone C, Cantarini L, Finetti M, Cattalini M, Filocamo G, et al. A national cohort study on pediatric Behçet's disease: crosssectional data from an Italian registry. Pediatr Rheumatol Online J 2017;15:84.

14. Noel N, Bernard R, Wechsler B, Resche-Rigon M, Depaz R, Le Thi Huong Boutin D, et al. Long-term outcome of neuro-Behçet's disease. Arthritis Rheumatol 2014; 66:1306-1

15. Ünver O, Ekinci G, Kutlubay BI, Thomas G, Sağer G, Eldeș HAcıfazlığlu N, et al. Evaluation of cases with cerebral thrombosis in children. Turk Pediatri Ars 2016; 51:87-93.

16. Demir S, Acari C, Basaran O, Sağ E, Karlı Oğuz K, Bilginer Y, et al. Paediatric Behçet's disease with sinus venous thrombosis: experience from three centres in Turkey. Clin Exp Rheumatol 2019; 37: 147-51.

17. Saip S, Akman-Demir G, Siva A. Neuro-Behçet syndrome. Handb Clin Neurol 2014;121:1703-23.

18. Hatemi G, Silman A, Bang D, Bodaghi B, Chamberlain AM, Gul A, et al. EULAR Expert Committee. EULAR recommendations for the management of Behçet's disease. Ann Rheum Dis 2008; 67: 1656-62.

19. Saadoun D, Wechsler B, Resche-Rigon M, Trad S, Le Thi Huoong D, Sbai A, et al. Cerebral venous thrombosis in Behçet's disease. Arthritis Rheum 2009; 61: 518-26. 